rethinking

art's histories

\title{
Art and human rights
}

Contemporary Asian contexts

\section{Caroline Turner and Jen Webb}

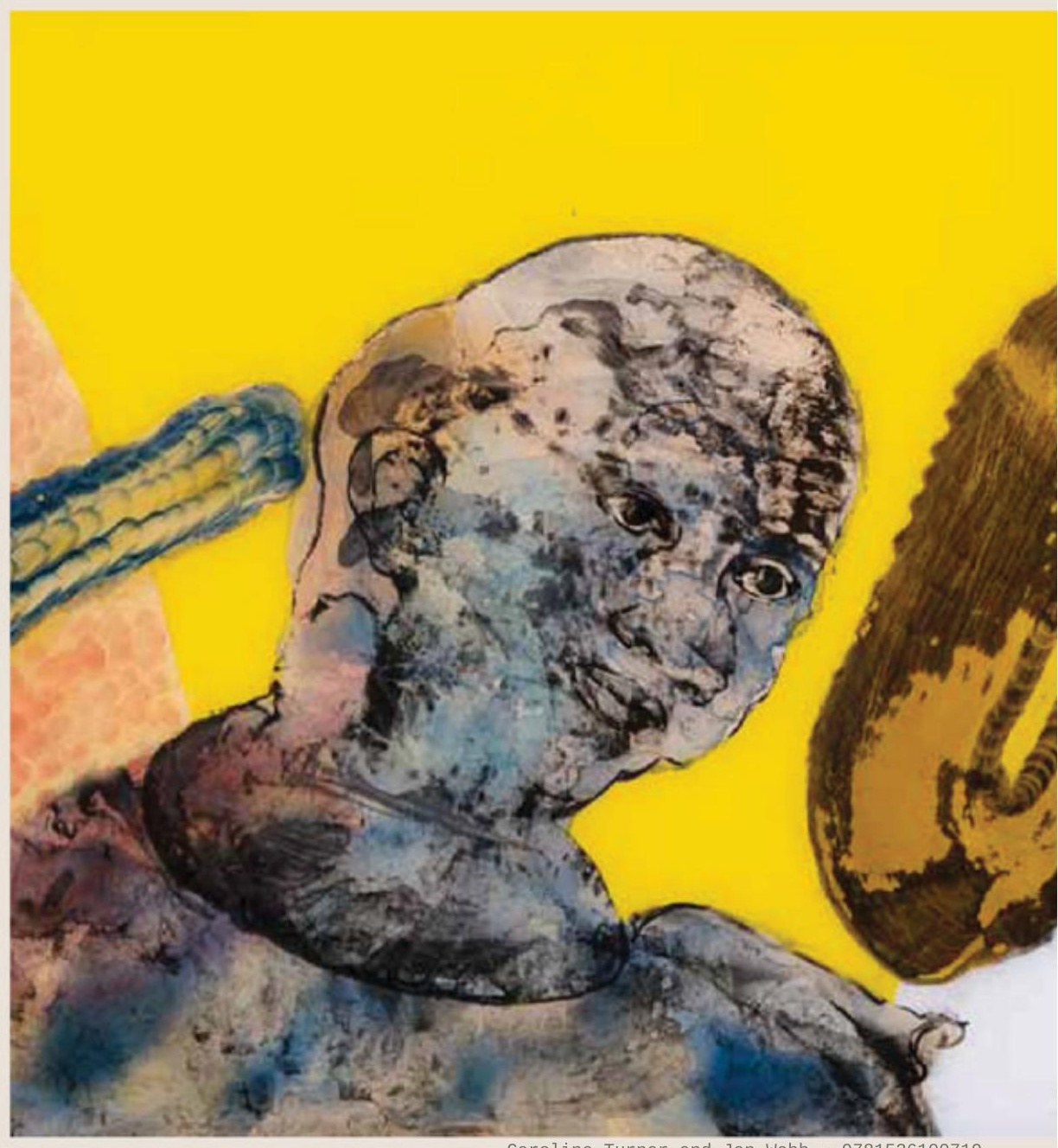


Art and human rights

MANCHESTER

1824

Manchester University Press 


\section{rethinking. art's histories}

SERIES EDITORS

Amelia G. Jones, Marsha Meskimmon

Rethinking Art's Histories aims to open out art history from its most basic structures by foregrounding work that challenges the conventional periodisation and geographical subfields of traditional art history, and addressing a wide range of visual cultural forms from the early modern period to the present.

Also available in the series

Art, museums and touch Fiona Candlin

The 'do-it-yourself' artwork: Participation from fluxus to relational aesthetics Anna Dezeuze (ed.)

The face of medicine: Visualising medical masculinities in late nineteenth-century Paris Mary Hunter

After the event: New perspectives in art history

Charles Merewether and John Potts (eds)

Photography and documentary film in the making of modern Brazil Luciana Martins

Women, the arts and globalization: Eccentric experience Marsha Meskimmon and Dorothy Rowe (eds)

Flesh cinema: The corporeal turn in American avant-garde film Ara Osterweil

After-affects|after-images: Trauma and aesthetic transformation in the virtual Feminist museum Griselda Pollock

Vertiginous mirrors: The animation of the visual image and early modern travel Rose Marie San Juan

The paradox of body, building and motion in seventeenth-century England Kimberley Skelton 
The newspaper clipping: A modern paper object Anke Te Heesen, translated by Lori Lantz

Screen/space: The projected image in contemporary art Tamara Trodd (ed.)

Timed out: Art and the transnational Caribbean Leon Wainwright

Performative monuments: Performance, photography, and the rematerialisation of public art Mechtild Widrich 
Blank page 


\section{Art and human rights \\ Contemporary Asian contexts}

\section{Caroline Turner and Jen Webb}

Manchester University Press 
Copyright (C) Caroline Turner and Jen Webb 2016

The rights of Caroline Turner and Jen Webb to be identified as the authors of this work have been asserted by them in accordance with the Copyright, Designs and Patents Act 1988.

Published by Manchester University Press

Altrincham Street, Manchester M1 7JA

www.manchesteruniversitypress.co.uk

British Library Cataloguing-in-Publication Data

A catalogue record for this book is available from the British Library

Library of Congress Cataloging-in-Publication Data applied for

ISBN 978 o 719090646 hardback

ISBN 978 o 719099571 paperback

First published 2016

The publisher has no responsibility for the persistence or accuracy of URLs for external or any third-party internet websites referred to in this book, and does not guarantee that any content on such websites is, or will remain, accurate or appropriate.

Typeset by Out of House Publishing 